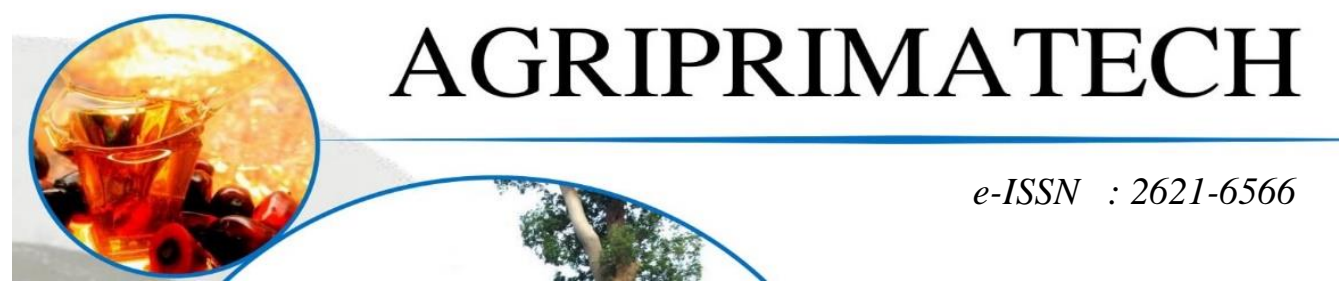

\title{
IDENTIFIKASI KETERKAITAN SEKTOR PERTANIAN DENGAN KEPARIWISATAAN DI KAWASAN TIGARAS
}

\author{
JHONSON A. MARBUN ${ }^{1}$, WAHYUNITA SITINJAK ${ }^{2}$, JURAINI ${ }^{3}$ \\ ${ }^{1,2}$ Dosen Program Studi Agribisnis, Fakultas Pertanian, Universitas Simalungun, \\ Pematangsiantar \\ ${ }^{3}$ Mahasiswa Program Studi, Fakultas Pertanian, Universitas Simalungun, Pematangsiantar \\ Email korespondensi:lucy88sitinjak@gmail.com
}

\begin{abstract}
ABSTRAK
Penelitian ini dilakukan di Nagori Tigaras dan Nagori Buttu Bayu Panei Raja Kecamatan Dolok Pardamean yang dalam penelitian ini dibagi menjadi dua ohiek wisata penelitian yaitu objek wisata alam dan objek wisata buatan. Untuk Objek v sendiri yaitu dilakukan di objek wisata Pantai Garoga, Pantai Paris, dan Pi

kemudian untuk objek wisata buatan yaitu penelitian dilakukan di Bukı ınaan Simarjarunjung dan Monumen KM Sinar Bangun. Penelitian ini bertujuan untuk mengetahui proporsi pengeluaran wisatawan, proporsi pengeluaran terkait atraksi, amenitas dan aksesibilitas, penggunaan hasil pertanian lokal dalam kuliner dan cenderamata serta kepuasan wisatawan diobjek wisata.Penelitian ini menggunakan metode gabungan antara pendekatan kuantitatif dan kualitatif.Hasil penelitian menunjukkan bahwa tidak terdapat perbedaan rata-rata pengeluaran wisatawan di objek wisata alam dengan objek wisata buatan di kawasan Tigaras. Hal ini di uji dari hasil perhitungan uji independent sample t-test dengan program SPSS 22.Berdasarkan hasil penelitian di kawasan Tigaras bahwa proporsi pengeluaran wisatawan untuk aksesibilitas, atraksi dan amenitas diobjek wisata alam dengan objek wisata buatan tidak berimbang, karena di setiap objek wisata memiliki harga yang berbeda-beda di setiap fasilitasnya dan daerah asal wisatawan yang berbeda-beda. Penggunaan hasil pertanian lokal dalam kuliner dan cenderamata di kawasan Tigaras lebih rendah dibandingkan dengan penggunaan hasil pertanian luar daerah, hal ini terjadi karena hampir keseluruhan dari setiap bahan baku yang didapatkan dari pengelola kuliner maupun cenderamata berasal dari luar daerah. Tingkat kepuasan wisatawan diobjek wisata alam dan diobjek buatan relatif sedang terkait atraksi, amenitas dan aksesibilitas di kawasan Tigaras.
\end{abstract}

Kata Kunci: Cenderamata, Lokal, Alam, Buatan, Tigaras, Kepuasan.

\section{PENDAHULUAN}

Kepariwisataan adalah sebagai sesuatu yang berhubungan dengan penyelenggaraan pariwisata (Yoeti, Oka A,2008). Pariwisata di Indonesia telah tumbuh dan berkembang menjadi lebih pesat, hal ini tidak terlepas dari peran serta masyarakat dalam pengembangan pariwisata. Penyelenggaraan pariwisata diarahkan untuk terwujudnya pemerataan pendapatan, dan pemerataan kesempatan berusaha. Meningkatnya sektor pariwisata akan membuka lapangan kerja dan 
Agriprimatech

Vol. 4 No. 2, April 2021

kesempatan usaha. Peningkatan pendapatan masyarakat dan pemerintah akan mendorong sektor yang terkait lebih berkembang.

Provinsi Sumatera Utara merupakan salah satu Provinsi terbesar di Indonesia yang terletak di Pulau Sumatera, yang banyak memiliki objekobjek wisata yang selalu dikunjungi para wisatawan lokal maupun mancanegara. Salah satu daerah yang memiliki banyak objek wisata dan sering dikunjungi wisatawan di Sumatera Utara adalah terdapat di Kabupaten Simalungun.

Simalungun merupakan salah satu kabupaten di Provinsi Sumatera Utara dengan Ibukota Raya. Kabupaten Simalungun terdiri dari 31 kecamatan dengan luas sebanyak 4.386,60 km atau $6,12 \%$ dari luas wilayah Sumatera Utara. Kabupaten Simalungun memiliki keanekaragaman sumber daya alam yang besar, sehingga merupakan daerah yang memiliki peluang investasi pariwisata yang cukup menjanjikan.

Menurut Gunn (2002), Atraksi merupakan daya tarik utama orang dalam melakukan suatu perjalanan. Atraksi memiliki fungsi yaitu sebagai daya pikat, perangsang orang untuk melakukan perjalanan dan sebagai pemberi kepuasan pengunjung. Amenitas yang dimaksud adalah tersedianya fasilitas sebagai tempattempat penginapan, restoran, hiburan, transport lokal yang memungkinkan wisatawan berpergian di tempat wisata tersebut serta alat-alat lain untuk komunikasi. Aksesibilitas yang dimaksud adalah tempatnya tidak terlalu jauh, tersedianya transport ke lokasi secara teratur, sering, murah, nyaman, dan aman.

Penilaian wisatawan terhadap objek wisata yang ada dapat digunakan sebagai acuan untuk pengembangan objek wisata di masa yang akan datang. Pengembangan pariwisata sesuai dengan apa yang diinginkan oleh wisatawan agar wisatawan merasa puas dengan apa yang diterimanya selama berkunjung di objek wisata tersebut.
e-ISSN : 2621-6566

Persaingan yang semakin tajam dalam industri pariwisata menyebabkan prioritas pengelola objek wisata harus berfokus pada kepuasan pengunjung. Setelah pengunjung merasa puas, hal tersebut pada akhirnya yang membuat wisatawan ingin berkunjung kembali ke tempat tersebut. (Murti dan Sujali, 2012).

\section{METODE PENELITIAN}

Lokasi penelitian dipilih secara $s$ engaja (purposive), yaitu di kawasan Tigarasdi Kecamatan Dolok Pardamean, Kabupaten Simalungun. Objek penelitian ini di kelompokan menjadi dua, yaitu objek wisata alam dan objek wisata buatan di Kawasan Tigaras.Objek Wisata Alam di Kawasan Tigaras yaitu Pantai Garoga, Pantai Paris danPantai Raya Tigaras. Untuk diobjek buatan yaitu di Bukit Indah Simarjarunjung dan Monumen KM Sinar Bangun.

Metode yang digunakan untuk wisatawan adalah Accidental sampling (secara kebetulan).Accidental Sampling yaitu teknik pengambilan sampel berdasarkan faktor spontanitas, dalam arti siapa saja yang secara tidak sengaja bertemu dengan peneliti dan sesuai dengan karakteristik (ciri-ciri), maka orang tersebut dapat dijadikan sebagai sampel atau responden. Hari pengamatan ditentukan setiap hari Sabtu dan Minggu begitu seterusnya selama kurang lebih 3 (tiga) bulan. Untuk pengusaha kuliner dan pengusaha cenderamata dapat dilakukan kapan saja dengan metode yang digunakan adalah purposive sampling (secara sengaja). Maksudnya, peneliti menentukan sendiri sampel/responden yang diambil tidak secara acak, tapi ditentukan sendiri oleh peneliti. Pengambilan sampel/responden berdasarkan "penelitian" peneliti mengenai siapa-siapa saja yang memenuhi persyaratan untuk dijadikan sampel/responden. Dengan demikian penetapan responden pada penelitian ini diharapkan agar dapat memberikan informasi dan gambaran terkait kuliner berbahan baku lokal serta cenderamata berbahan baku lokal yang ada di 
Agriprimatech

kawasan Tigaras. Jumlah responden yang diambil adalah 5 pengusaha kuliner dan 2 pengusaha cenderamata.

Adapun metode analisia data yang digunakan adalah metode gabungan antara pendekatan kuantitatif dan kualitatif. Proses penyederhanaan data kedalam bentuk yang mudah untuk dibaca dan diinterpretasikan.

Untuk menguji hipotesis yang telah diajukan digunakan metode sebagai berikut :

\section{Uji Beda Rata-rata}

Dalam penelitian ini menggunakan metode independent sample t-test. Uji ini digunakan untuk mengetahui proporsi kunjungan wisatawan di kawasan Tigaras. Responden dalam penelitian ini terbagi dalam dua kelompok, yaitu wisatawan yang berkunjung di objek wisata alam dan wisatawan yang berkunjung di objek wisata buatan. Rumusnya sebagai berikut :

$$
\begin{gathered}
\mathrm{t}=\frac{\bar{X}_{1}-\bar{X}_{2}}{\operatorname{Sp} \sqrt{\left(\frac{1}{\mathrm{n}^{1}}+\frac{1}{\mathrm{n}_{2}}\right)}} \\
\mathrm{Sp}=\sqrt{\frac{\left(\mathrm{n}_{1}-1\right) \mathrm{S}_{1}{ }^{2}+\left(\mathrm{n}_{2}-1\right) \mathrm{S}_{2}{ }^{2}}{\mathrm{n}_{1}+\mathrm{n}_{2}-2}}
\end{gathered}
$$

dimana :

$\overline{\mathrm{X}_{1}}$ atau $\overline{\mathrm{X}_{2}}=$ Rata-rata responden kelompok 1 atau 2

$\mathrm{n}_{1}$ atau $\mathrm{n}_{2}=$ Jumlah responden kelompok 1 atau 2

$\mathrm{S}_{1}$ atau $\mathrm{S}_{2}=$ Standard deviasi kelompok 1 atau 2

df $=$ degree of freedom (derajat kebebasan)

$\mathrm{Sp} \quad=$ Varian populasi

2. Untuk mengetahui penggunaan hasil pertanian lokal dalam kuliner dan cenderamatadi kawasan Tigaras dengan menggunakan perhitungan persentase. Perhitungan persentase

dimaksudkan untuk mengetahui besar kecilnya frekuensi penggunaan hasil pertanian lokal dalam kuliner dan cenderamata berdasarkan harga, dengan rumus sebagai berikut:

$$
\text { Penggunaan Pertanian Lokal } \frac{\text { Harga Kandungan Lokal }}{\text { Harga Pokok Penjualan }} \times 100 \%
$$

3.

Untuk mengetahui proporsi pengeluaran wisatawan untuk aksesibilitas (ongkos transportasi dan tiket masuk), atraksi (sewa wahana dan cenderamata),

Pengeluaran Wisatawan untuk 3A= $\frac{\text { Pengeluaran Per Item }}{\text { Pengeluaran Total }} \times 100 \%$

4.Skala Likert Perhitungan kepuasan wisatawan terhadap objek wisata yang ada di kawasan Tigarasmenggunakan amenitas (konsumsi, kenyamanan, parkir, fasilitas lain) di kawasan Tigaras dengan menggunakan rumus sebagai berikut : skala likert.Skala likert menurut Sugiyono (2007) merupakan suatu skala yang digunakan untuk mengungkap sikap pro dan kontra, positif dan negatif, setuju dan 
Agriprimatech

Vol. 4 No. 2, April 2021

e-ISSN :2621-6566

tidak setuju terhadap suatu objek sosial.

Penetapan skor yang diberikan untuk

mengukur kepuasan wisatawan terhadap

objek wisata yang ada dikawasan Tigaras menggunakan pembobotan

Sangat Puas

Puas

(P)

(SP)

diberiskor 5;

Cukup Puas

$(\mathrm{CP})$

diberiskor 4;

Kurang Puas

$(\mathrm{KP})$

diberiskor 3;

Tidak Puas

(TP)

diberiskor 2;

Kemudian ditentukan kelas interval dengan menggunakan rumus :

Dimana:

$$
\frac{\text { NT }- \text { NR }}{\text { Jumlah Kelas }}
$$

NT : Nilai Tertinggi

NR : Nilai Rendah

HASIL DAN PEMBAHASAN

A. Deskripsi Daerah Penelitian Letak dan Keadaan Geografis

Penelitian ini dilakukan di Nagori

Tigaras dan Nagori Buttu Bayu Panei Raja Kecamatan Dolok Pardamean, yang merupakan salah satu kecamatan

Tabel 1. Luas Wilayah Kecamatan Dolok Pardamean Berdasarkan Nagori/ Kelurahan

\begin{tabular}{clcc}
\hline No Nagori/Kelurahan & $\begin{array}{c}\text { Luas Wilayah } \\
\left(\mathrm{Km}^{2}\right)\end{array}$ & Persentase $(\%)$ \\
\hline 1 & Buttu Bayu Panei Raja & 7,03 & 10,35 \\
2 & Dolok Saribu & 7,50 & 11,05 \\
3 & Nagori Bayu & 1,50 & 2,21 \\
4 & Parik Sabungan & 9,05 & 13,33 \\
5 & Sibuntuon & 10,72 & 15,79 \\
6 & Sihemun Baru & 0,90 & 1,33 \\
7 & Silabah Jaya & 1,78 & 2,62 \\
8 & Sirube Rube & 6,86 & 10.10 \\
9 & Tigaras & 8,50 & 12,52 \\
10 & Tanjung Saribu & 5,86 & 8,63 \\
11 & Togu Domu Nauli & 8,20 & 12,08 \\
\hline \multicolumn{2}{r}{ Total } & 67,90 & 100 \\
\hline
\end{tabular}

Sumber: BPS Simalungun, Kecamatan Dolok Pardamean Dalam Angka, 2019

Dari Tabel 1 tersebut dapat diketahui luas wilayah Kecamatan Dolok Pardamean terbesar berada di Kelurahan/Nagori Sibuntuon seluas $10,72 \mathrm{Km}^{2}(15,79 \%)$ dan wilayah terkecil berada di Kelurahan/Nagori Sihemun Baru seluas $0,90 \mathrm{Km}^{2}$ (1,33\%).

B. Deskripsi Objek Penelitian dan Karakteristik Sampel

1. Profil Objek Wisata di Kawasan Tigaras di Kabupaten Simalungun. Luas wilayahKecamatan Dolok Pardamean adalah $67,90 \mathrm{Km}^{2}$ dengan ketinggian $1236,1 \mathrm{~m}$ diatas permukaan laut.

Berikut tabel nama kelurahan dan luas wilayah yang terdapat di Kecamatan Dolok Pardamean. 
Agriprimatech

Vol. 4 No. 2, April 2021

akses jalan yang masih kurang baik, berlubang dan sempit membuat kendaraan harus berhati-hati untuk melaluinya, salah satunya harus dilalui saat akan memasuki area kawasan wisata Monumen KM Sinar Bangun. Sebelum memasuki area parkir untuk lokasi kawasan pantai, seperti Pantai Paris, Pantai Garoga, dan Pantai Raya Tigaras pengunjung juga harus menuruni akses jalan yang cukup curam sehingga membuat kenderaan harus berhati-hati saat melaluinya.

Monumen KM Sinar Bangun di resmikan pada tanggal 2 Mei 2019 di kawasan pelabuhan Tigaras dengan tujuan untuk mengenang para korban tenggelamnya KM Sinar Bangun di perairan Danau Toba. Ini merupakan monumen kesedihan sekaligus tempat ziarah bagi keluarga korban, kemudian sebagai monumen peringatan serta menjadi landmark kawasan sekaligus tempat wisata.

Di objek Monumen KM Sinar Bangun, tidak hanya untuk keluarga korban, pengunjung juga dapat berziarah serta mendapatan informasi berupa nama-nama korban yang terukir di monumen tersebut.Selain itu, pengunjung dapat berfoto di area monumen serta pengunjung juga dapat menikmati pemandangan danau Toba karena letak nya yang tidak jauh dari pelabuhan Tigaras.

Rekreasi air merupakan kegiatan utama di kawasan wisata Pantai Tigaras.
e-ISSN :2621-6566

Pemandangannya yang indah dan adanya beberapa fasilitas wahana seperti berbagai macam water sport, fasilitas hiburan seperti live music.Amenitas atau fasilitas yang ada di Kawasan Pantai Paris, Pantai Garoga dan Pantai Raya Tigaras sudah cukup lengkap. Mulai dari toilet, kamar ganti, kantin, pondok, pondok/tikar, photo booth, penginapan sampai Musholah juga sudah tersedia.

Bukit Indah Simarjarunjung pertama kali dibangun pada tanggal 27 Desember 2016 oleh Erwin Gurning yang terinspirasi dari rumah-rumah pohon yang ada di Yogyakarta.Disamping lokasi yang strategis, pengunjung juga dapat menikmati langsung pemandangan alam Danau Toba dari bukit. Sembari cuci mata, pengunjung dapat berfoto di beberapa spot foto yang tersedia, seperti Sky Bike, Sun Flower, balon udara dan masih banyak lagi yang lainnya. Fasilitas utama lainnya yang ada di BIS adalah halaman parkir, Musholla, Gazebo dan toilet.

\section{Deskripsi Responden}

Responden yang digunakan dalam penelitian ini dibagi menjadi 2 (dua) yaitu wisatawan dan pegusaha.Sampel terdiri dari 60 (per keluarga/rombongan) wisatawan, 5 pengusaha kuliner dan 2 pengusaha cendera mata.

a. Karakteristik berdasarkan jenis kelamin

Tabel2.Karakteristik Responden Berdasarkan Jenis Kelamin dibulan Januari-Maret

\begin{tabular}{|c|c|c|c|c|c|}
\hline \multirow[t]{2}{*}{ No } & \multirow{2}{*}{$\begin{array}{c}\text { Jenis } \\
\text { Responden } \\
\end{array}$} & \multicolumn{2}{|c|}{ Jenis Kelamin } & \multirow{2}{*}{$\begin{array}{c}\text { Jumlah } \\
\text { (Jiwa) }\end{array}$} & \multirow{2}{*}{$\begin{array}{c}\text { Persentase } \\
(\%)\end{array}$} \\
\hline & & Laki-laki & Perempuan & & \\
\hline 1 & Wisatawan & 54 & 6 & 60 & 89,5 \\
\hline 2 & Pengusaha Kuliner & 0 & 5 & 5 & 7,5 \\
\hline \multirow[t]{2}{*}{3} & Pengusaha Cenderamata & 0 & 2 & 2 & 3 \\
\hline & Total & 54 & 13 & 67 & 100 \\
\hline
\end{tabular}

Sumber: Data Primer diolah 2020

Dari tabel diatas dapat dilihat bahwa responden berjenis kelamin lakilaki lebih banyak daripada responden berjenis kelamin perempuan. Responden laki-laki terbanyak ada di jenis responden wisatawan dengan jumlah 54 jiwa, dan responden laki-laki paling sedikit ada di jenis responden pengusaha kuliner dan pengusaha cendera mata dengan jumlah 0 jiwa. Sedangkan responden perempuan terbanyak ada di jenis responden wisatawandengan jumlah 6 jiwa, dan responden perempuan paling sedikit ada di jenis responden 
Agriprimatech

Vol. 4 No. 2, April 2021

e-ISSN :2621-6566

Pengusaha cenderamata berjumlah 2 jiwa.

b. Karakteristik

responden

berdasarkan umur

Responden terbanyak berada di kategori wisatawan antara umur 41-50 tahun dengan jumlah 23 jiwa.Sedangkan responden yang paling sedikit berada di

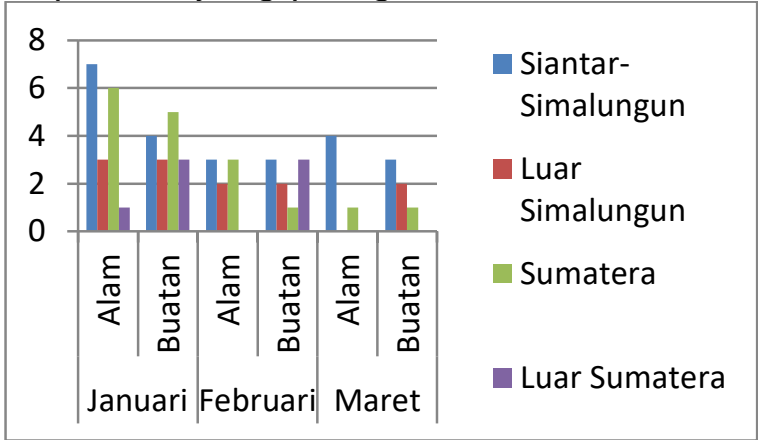

kategori pengusaha cenderamata antara umur 15-30 dan antara umur $>51$ tahun dengan jumlah 0 jiwa.

c. Karakteristik responden berdasarkan daerah asal

Untuk melihat karakteristik responden berdasarkan daerah asal dapat dilihat pada grafik berikut ini.

Gambar 1. Grafik Kunjungan Wisatawan kekawasan Tigaras Menurut Waktu dan Asal Kedatangan

Berdasarkan jumlah kunjungan wisatawan ke kawasan Tigaras jumlah wisatawan pada bulan Januari diobjek alam sebanyak 17 rombongan dan diobjek buatan sebanyak 15 rombongan. Di bulan Februari jumlah kunjungan wisatawan mengalami penurunan baik itu diobjek alam maupun diobjek buatan, di objek alam jumlah kunjungan wisatawan sebanyak 8 rombongan dan diobjek buatan sebanyak 9 rombongan, kemudian jumlah kunjungan wisatawan mengalami penurunan kembali di bulan Maret yaitu sebanyak 5 rombongan diobjek alam dan 6 rombongan diobjek buatan. Dapat dilihat pula bahwa kunjungan wistawan menurut daerah asal yaitu daerah Siantar-Simalungun sebanyak 24 rombongan, kemudian jumlah kunjungan wisatawan di luar simalungun sebanyak 12 rombongan, jumlah kunjungan wisatawan yang berasal dari Sumatera sebanyak 17 rombongan serta jumlah kunjungan wisatawan diluar sumatera sebanyak 7 rombongan.Ini dapat diartikan bahwa semakin jauh dari objek wisata semakin sedikit frekuensi kunjungan wisatawan, terkecuali wisatawan yang berkunjung dari daerah asal Sumatera. Ini terjadi karena wisatawan di daerah SiantarSimalungun lebih dekat jarak daerah asalnya dengan lokasi wisata, kemudian di daerah luar simalungun banyak pilihan objek wisata, untuk di daerah Sumatera dapat dilihat pada grafik diatas bahwa frekuensi kunjungan wisatawan terbanyak yaitu dibulan Januari karena mereka berkunjung untuk menghabiskan waktu pada saat libur tahun baru selebihnyakarena ada tugas lainya kemudian menyempatkan waktu untuk berkunjung di objek wisata kawasan Tigaras, begitu juga bagi wisatawan yang berasal dari daerah luar Sumatera.

d. Karakteristik wisatawan berdasarkan objek wisata

Tabel 3. Karakteristik WisatawanBerdasarkan Objek Wisata Tujuan dibulan Januari-Maret

\begin{tabular}{cccc}
\hline No & Objek Wisata & $\begin{array}{c}\text { Jumlah } \\
\text { Wisatawan }\end{array}$ & $\begin{array}{c}\text { Persentase } \\
(\%)\end{array}$ \\
\hline 1 & BIS & 17 & 28,3
\end{tabular}


Agriprimatech

Vol. 4 No. 2, April 2021

\begin{tabular}{cccc}
2 & $\begin{array}{c}\text { M. KM Sinar } \\
\text { Bangun }\end{array}$ & 13 & 21,7 \\
3 & Pantai Garoga & 10 & 16,6 \\
4 & Pantai Paris & 13 & 21,7 \\
5 & Pantai Raya & 7 & 11,7 \\
\hline & Jumlah & 60 & 100 \\
\hline
\end{tabular}

Sumber: Data Primer diolah 2020

Berdasarkan tabel di atas dapat dilihat bahwa di objek wisata tujuan utama wisatawan adalahdiobjek Bukit Indah Simarjarunjung mencapai angka $28,3 \%$, kemudian Monumen KM Sinar Bangun mencapai angka 21,7\%, selanjutnya Pantai Garoga mencapai angka $16,6 \%$ dan Paris mencapai $21,7 \%$ serta yang terakhir adalah Pantai Raya mencapai $11,7 \%$ dibulan Januari sampai dengan bulan Maret.

3. Pengeluaran Wisatawan di Objek Wisata Kawasan Tigaras

Rata-rata

pengeluaran

wisatawan di objek wisata buatan Bukit Indah Simarjarunjung sebesar Rp284.176. Pada objek wisata alam Pantai Garoga rata-rata pengeluaran seluruh wisatawan sebesar Rp224.300, di objek wisata alam Pantai Paris ratarata pengeluaran seluruh wisatawan sebesar Rp 281.538, kemudian di objek wisata alam Pantai Raya rata-rata pengeluaran seluruh wisatawan sebesar Rp 220.000 dan di objek wisata buatan Monumen KM Sinar Bangun rata-rata pengeluaran seluruh wisatawan sebanyak Rp146.538.Jika di hitung, maka rata-ratapengeluaran wisatawan diobjek wisata alam adalah sebanyak Rp257.867 dan rata-rata pengeluaran wisatawan diobjek wisata buatan adalah sebanyak Rp224.533.

4. Pengeluaran Wisatawan Berdasarkan Amenitas, Atraksi dan Aksesibilitas

Rata-rata

wisatawan berdasarkan amenitas, atraksi dan aksesibilitas di objek wisata alam adalah sebesar Rp 257.867 dan rata-rata pengeluaran wisatawan berdasarkan amenitas, atraksi dan aksesibilitas di objek wisata buatan adalah sebesar Rp 224.533.
e-ISSN :2621-6566

5. Penggunaan Hasil Pertanian Lokal dalam Kuliner dan Cendera Mata di Kawasan Tigaras

Peran serta masyarakat dalam pertaniannya di kawasan Tigaras masih kurang mendukung dalam pemanfaatan hasil-hasil pertaniannya, mengingat begitu banyaknya potensi yang dimiliki kawasan tersebut. Pemanfaatan hasil pertanian lokal dikawasan Tigaras hanya memanfaatkan ikan hasil tangkapan maupun ikan kerambah saja.Sedangkan dalam kuliner bumbu rempah sangat berperan penting dalam menciptakan rasa dalam suatu hidangan.

Di kawasan Tigaras sendiri pemilik usaha kuliner pada umumnya memanfaatkan bumbu rempah yang berasal dari luar daerah, seperti cabai, bawang, jahe serta bumbu pelengkap lainya yang di beli dari Pematang Siantar dan daerah lainya.Dari pemanfaatan hasil pertanian lokal yang kurang dikawasan Tigaras sehingga dapat diartikan bahwa kurangnya hubungan produksi pertanian dengan potensi wisata dikawasan Tigaras.

Cenderamata merupakan salah satu infrastruktur pariwisata di suatu kawasan objek wisata karena cenderamata dapat mencerminkan kearifan lokal daerah kawasan objek wisata setempat. Namun di daerah kawasan Tigaras sendiri belum adanya penggiat kerajinan yang membuat kerajinan khas Simalungun ataupun kerajinan khas daerah tersebut. Pengusaha cenderamata dikawasan Tigaras rata-rata memanfaatkan barang jadi yang didapatkan dari luar daerah kawasan Tigaras seperti pernak-pernik, ukiran kayu, kaos, tas anyam dan lainnya.

6. Kepuasan Wisatawan diobjek Wisata Kawasan Tigaras 
Agriprimatech

Vol. 4 No. 2, April 2021

Tanggapan responden terhadap suatu objek wisata mungkin saja berbeda pada setiap orang.Kadang orang merasa puas terhadap kualitas pelayanannya jika orang tersebut mendapatkan pelayanan yang memuaskan dari suatu objek wisata maupun sebaliknya. Sarana penunjang Pariwisata juga mempengaruhi tingkat kepuasan wisatawan terhadap pelayanan di objek wisata. Untuk akomodasi sendiri sudah tersedia di beberapa objek wisata yang diteliti, namun minat wisatawan masih kurang untuk menikmati akomodasi yang telah disediakan oleh pihak pengelola objek wisata, karena beberapa pertimbangan bahwa mereka lebih memilih untuk bermalam dirumah sanak saudara dan yang lainnya memilih untuk menginap di penginapan lain karena mereka berniat untuk melanjutkan perjalanan diobjek wisata lain.Untuk biro perjalanan sendiri belum tersedia di objek wisata yang diteliti. Kemudian transportasi, belum tersedia jasa angkutan untuk memasuki beberapa objek wisata yang diteliti. Untuk jasa boga dan restoran sudah tersedia di semua objek wisata yang diteliti mengingat bahwa setiap wisatawan pastinya selalu memerlukan makanan dan minuman dalam menikmati perjalanan wisatanya. Kemudian berdasarkan hasil survei jasa fasilitas keuangan dianggap penting penyediaannya bagi wisatawan, namun dari kondisi eksisting tidak ada ketersediaan jasa keuangan dilokasi wisata. Jadi berdasarkan kebutuhan wisatawan yang belum terpenuhi, dibutuhkan jasa keuangan terutama ATM Center dalam mendukung kegiatan
e-ISSN :2621-6566

wisatawan dalam berwisata. Untuk atraksi wisata sendiri dalam hal pertunjukan wisata seperti tarian daerah di objek wisata yang diteliti tidak ada, mengingat bahwa Simalungun kaya akan kebudayaan nya, sangat disayangkan pertunjukan dalam unsur kedaerahan tidak di kembangkan di suatu objek wisata, mengingat di dalam kepariwisatan unsur kedaerahan dapat menjadi salah cara untuk memperkenalkan kebudayaan daerah kepada khalayak ramai yang datang dari berbagai asal daerah tempat tinggalnya. Kemudian untuk cenderamata sendiri di beberapa objek yang diteliti sudah tersedia, dari jenis makanan, pernak pernik, kaos, kain ulos dan lain sebagainya.

Untuk mengetahui kepuasan wisatawan di beberapa objek wisata pada penelitian ini dinilai dari aspek $3 \mathrm{~A}$ yaitu Atraksi, Amenitas dan Aksesibilitas.

C. Proporsi Pengeluaran Wisatawan di Objek Wisata Alam dengan Buatan

Proporsi pengeluaran wisatawan di beberapa objek wisata pada penelitian ini dinilai dari aspek 3A yaitu Atraksi, Amenitas dan Aksesibilitas. Jika :

Ho : Diduga tidak ada perbedaan ratarata pengeluaran wisatawan di objek wisata alam dengan objek wisata buatan di kawasan Tigaras.

$\mathrm{Ha}$ : Diduga ada perbedaan rata-rata pengeluaran wisatawan di objek wisata alam dengan objek wisata buatan di kawasan Tigaras.

Hipotesis diatas kemudian akan dibuktikan dengan uji independent sample $t$-test yang hasilnya bisa dilihat dalam tabel berikut.

Tabel 4. Hasil UjiIndependent Sample t-test mengenai Proporsi Pengeluaran Wisatawan di Objek Alam dan Objek Buatan Kawasan Tigaras 


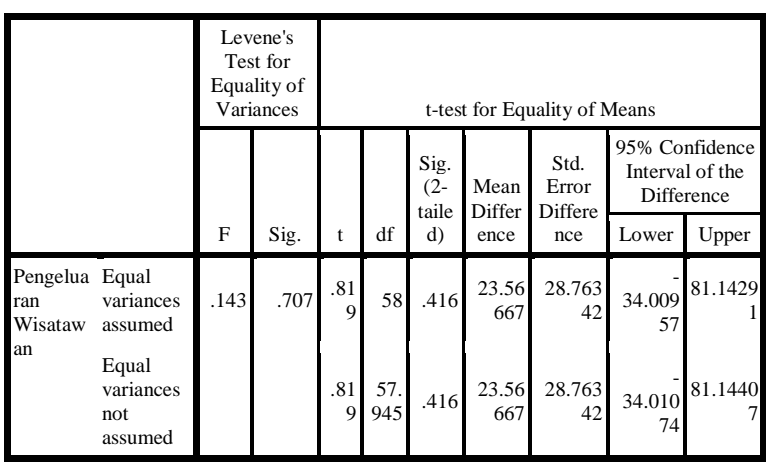

Sumber:DataPrimer diolah 2020

Berdasarkan hasil pengujian hipotesis diatas guna untuk menguji uji beda menggunakan perhitungan uji independent sample t-test yang dilakukan menggunakan SPSS 22 menunjukkan bahwa nilai Sig. (2tailed)equal variances assumed sebesar 0,416 . Hal ini menunjukkan nilai Sig. (2tailed) 0,416>0,05, maka berdasarkan hasil pengujian independent sample $t$ test dapat disimpulkan bahwatidak terdapat perbedaan yang signifikan antara pengeluaran wisatawan di objek wisata alam dengan objek wisata buatan di kawasan Tigaras.Meskipun secara statistik tidak terdapat perbedaan ratarata pengeluaran wisatawan diobjek

Tabel 5. Pengeluaran Wisatawan Untuk Aksesibilitas, Atraksi dan Amenitas diobjek

\section{Wisata Alam dengan Objek Wisata Buatan}

\begin{tabular}{ccccc}
\hline No & $\begin{array}{c}\text { Objek } \\
\text { Wisata }\end{array}$ & $\begin{array}{c}\text { Aksesib } \\
\text { ilitas } \\
(\%)\end{array}$ & $\begin{array}{c}\text { Atraksi } \\
(\%)\end{array}$ & $\begin{array}{c}\text { Amenitas } \\
(\%)\end{array}$ \\
\hline 1 & Alam & 46,8 & 17,9 & 35,3 \\
2 & Buatan & 61,9 & 17,6 & 20,5 \\
\hline
\end{tabular}

Sumber: Data Primer diolah 2020

Proporsi pengeluaran wisatawan untuk aksesibilitas, atraksi dan amenitas diobjek wisata alam dengan objek wisata buatan tidak berimbang, karena di setiap objek wisata memiliki harga yang berbeda-beda di setiap fasilitasnya dan lokasi wisatawan yang berbeda-beda.

Untukpengeluaran wisatawan terkait aksesibilitas di objek alam yaitu mencapai angka 46,8 \%, atraksi mencapai angka 17,9\% dan pengeluaran terkait amenitas mencapai angka 35,3\%. Sedangkan pengeluaran wisatawan alam dengan diobjek buatan, namun pada kenyataannya rata-rata pengeluaran wisatawan di objek wisata buatan Bukit Indah Simarjarunjung lebih tinggi dan di objek wisata Monumen KM Sinar Bangun lebih rendah dibanding dengan pengeluaran wisatawan diobjek wisata alam.

D. Proporsi Pengeluaran Wisatawan untuk Aksesibilitas, Atraksi dan Amenitas Objek Wisata Alam dan

Untuk melihat pengeluaran wisatawan untuk aksessibilitas, atraksi dan amenitas diobjek wisata dapat dilihat pada tabel berikut ini. Objek Wisata Buatan 
Agriprimatech

Vol. 4 No. 2, April 2021

dalam penelitian ini adalah mencapai angka 27,7\%.Dalam metode penyelesaian ini, data penggunaan hasil pertanian lokal dalam kuliner yang diambil merupakan data yang didapat serta mewakili dari keseluruhan data responden pengusaha kuliner di kawasan Tigaras, dengan pertimbangan yaitu kuliner tersebut merupakan hidangan yang paling banyak diminati oleh konsumendi semua lokasi usaha kuliner kawasan Tigaras yang di teliti dan merupakan salah satu hidangan yang memanfaatkan hasil pertanian lokal.

Dalam uraian diatas dapat diartikan bahwa pelestarian dalam bidang kuliner di kawasan Tigaras belum terpenuhi berdasarkan 3M, yaitu memelihara, memanfaatkan, dan mengembangkan, karena jika dilihat dari penggunaan hasil pertanian lokal yang digunakan hanya memanfaatkan ikan saja dari perairan Danau Toba tepatnya dikawasan Tigaras. Sementara untuk bahan-bahan lain seperti sayur-sayuran dan bumbu rempah rata-rata didapatkan dari daerah luar kawasan Tigaras.Padahal dilihat dari potensi lokalnya sudah ada, tetapi tidak digunakan ataupun di manfaatkan dengan baik.Namun jika dimanfaatkan dengan baik ini dapat menunjang perekonomian masyarakat atau para petani, menghemat biaya bagi pengusaha serta mendukung sektor kepariwisataan terkait kekayaan lokal di daerah kawasan Tigaras. Sedangkan penggunaan bahan baku pada pengusaha cenderamata dikawasan Tigaras rata-rata memanfaatkan barang jadi yang didapatkan dari luar daerah kawasan Tigaras.

\section{F. Kepuasan Wisatawan terhadap Objek Wisata di kawasan Tigaras}

Tingkat kepuasan wisatawan di objek wisata dalam penelitian ini dibagi menjadi 2 , berdasarkan objek wisata alam dan objek wisata buatan serta dinilai dari aspek $3 \mathrm{~A}$ yaitu Atraksi, Amenitas dan Aksesibilitas.

Diobjek alam untuk kepuasan wisatawan terkait Atraksi dalam kategori
e-ISSN :2621-6566

sedang (96,7\%), Amenitas dalam kategori sedang (100\%) dan Aksesibilitas dalam kategori rendah $(53,3 \%)$. Sedangkan diobjek buatan untuk kepuasan wisatawan terkait Atraksi sedang (100\%), Amenitas sedang (100\%) dan Aksesibilitas sedang (56,7\%).Dapat disimpulkan bahwa kepuasan wisatawan diobjek wisata alam dan diobjek wisata buatan relatif sedang terkait atraksi, amenitas dan aksesibilitas di kawasan Tigaras. Ini terjadi karena dari beberapa tanggapan wisatawan dibeberapa objek wisata kawasan Tigaras kurang sesuai dengan apa yang diharapkan mereka, seperti keadaan di objek wisata, seperti kebersihannya, wahana permainan yang terbatas yang kurang membuat minat wisatawan ingin berlama-lama untuk berwisata diobjek wisata tersebut. Kemudian dapat dilihat juga pada uraian diatas bahwa untuk tingkat kepuasan wisatawan diobjek wisata alam terkait aksesibilitas rendah, ini terjadi karena akses jalan menuju lokasi wisata sempit dan dibeberapa titik jalan masih ada yang berlubang, kemudian dibeberapa objek wisata seperti Pantai Garoga, Pantai Paris dan Pantai Raya untuk akses jalan menuju tempat parkir cukup curam, sehingga wisatawan yang berkunjung harus lebih berhati-hati dalam mengemudikan kenderaanya.

\section{KESIMPULAN}

Tidak terdapat perbedaan ratarata pengeluaran wisatawan di objek wisata alam dengan objek wisata buatan di kawasan Tigaras. Hal ini bisa dilihat dari hasil perhitungan uji independent sample t-test, diketahui bahwa nilai Sig. (2-tailed) equal variances assumed sebesar 0,416. Hal ini menunjukkan nilai Sig. (2-tailed) 0,416>0,05.

Proporsi pengeluaran wisatawan untuk aksesibilitas, atraksi dan amenitas diobjek wisata alam dengan objek wisata buatan tidak berimbang, karena di setiap objek wisata memiliki harga yang berbeda-beda di setiap fasilitasnya dan daerah asal wisatawan yang berbeda- 
Agriprimatech

Vol. 4 No. 2, April 2021

beda.Penggunaan hasil pertanian lokal dalam kuliner dan cenderamata di kawasan Tigaras lebih rendah dibandingkan dengan penggunaan hasil pertanian luar daerah, hal ini terjadi karena hampir keseluruhan dari setiap bahan baku yang didapatkan dari pengelola kuliner maupun cenderamata berasal dari luar daerah.

Untuk penggunaan hasil pertanian lokal sendiri bagi pengusaha kuliner hanya mengandalkan ikan nila dan ikan mas saja yang diperoleh dari pertanian lokal di kawasan Tigaras. Penggunaan hasil pertanian lokal sendiri dalam kuliner hanya mencapai angka $27,7 \%$, sedangkan untuk pengusaha cenderamata rata-rata memanfaatkan barang jadi yang didapatkan dari luar daerah kawasan Tigaras.

Tingkat kepuasan wisatawan di objek wisata alam dan diobjek buatan relatif sedang terkait atraksi, amenitas dan aksesibilitas di kawasan Tigaras.Namun tingkat kepuasan wisatawan diobjek wisata alam terkait aksesibilitas rendah, dikarenakan akses jalan yang sempit dan berlubang serta curam membuat beberapa wisatawan kurang nyaman selama menikmati perjalanan wisata.

\section{DAFTAR PUSTAKA}

Badan Pusat Statistik Kabupaten Simalungun. 2019. Dolok Pardamean Dalam Angka 2019. Badan Pusat Statistik Kabupaten Simalungun. Pematang Siantar.

Gunn, Clare A. 2002. Tourism Planning; basic, concepts, cases (Fourth Edition), Routledge New York \& London.

Murti, H.S., Sujali. 2012. Persepsi Wisatawan terhadap Pengembangan Objek Wisata Batang Dolphin Center. Jurnal 1 (1),pp. 260-267.

Sugiyono. 2008. Metode Penelitian Kuantitatif Kualitatif dan $R \& D$. Alfabeta. Bandung.
e-ISSN :2621-6566

Yoeti, Oka, A. 2008. Perencanaan dan Pengembangan Pariwisata.PT Pradnya Paramita. Jakarta. 
